\title{
Mobilność rzeczy
}

Przedmioty — naturalne bądź wytworzone przez człowieka i towarzyszące mu w jego życiu - od dawna stanowią przedmiot zainteresowania w badaniach nad kulturą. Ostatnio to zainteresowanie stało się szczególnie intensywne, otwierając się na nowe propozycje, takie jak humanistyka nie-antropocentryczna (E. Domańska), teoria Aktora-Sieci (B. Latour) czy refleksja nad indywidualną i zbiorową pamięcią (B. Shallcross). Wiąże się to nie tylko z odkrywaniem nieobecnych dotąd w refleksji kulturoznawczej aspektów rzeczywistości, ale też z widocznym przyrostem rzeczy w życiu współczesnego człowieka, który próbuje odnaleźć się w świecie przez rzeczy zdominowanym.

Nie powinno zatem dziwić, że na III Zjazd Polskiego Towarzystwa Kulturoznawczego, który odbył się jesienią 2017 roku w Poznaniu pod hasłem „Kultury w ruchu. Migracje, transfery, epistemologie", zgłoszono aż dwie, wywodzące się z różnych ośrodków, propozycje paneli dyskusyjnych poświęconych rzeczom w ruchu. Pierwsza z nich, którą sygnowali badacze z Instytutu Kulturoznawstwa Uniwersytetu Wrocławskiego, Stefan Bednarek i Izolda Topp, ujęła tę problematykę pod hasłem: „Wędrówki rzeczy”. Przedmiotem panelu miały być więc rzeczy, które wędrują wraz z migrującym człowiekiem; które zostawiał on, kiedy wyruszał w drogę; które zastawał u jej celu; które przywoził z dalekich podróży; które otrzymywał i które dawał; które niszczy lub z pietyzmem kolekcjonuje i przechowuje. Wiek XX i początek wieku XXI pozwalają na obserwację rzeczy towarzyszących człowiekowi w drodze, na przeobrażenia funkcji owych „ruchomości” (przywołuję to określenie za O. Tokarczuk), nadawanych im znaczeń i wiązanych z nimi wartości; obrazują przemiany, jakim podlega człowiek, którego kondycję określa ruch.

Druga propozycja padła ze strony badaczy kultury związanych z poznańską etnologią, Pawła Kuligowskiego i Agaty Stanisz, i nosiła tytuł „Mobilne rzeczy”. Zwracali oni uwagę, że mobilność, ruch, przepływ to w naukach społecznych aktualnie jedne z bardziej nośnych pojęć stosowanych do opisywania i analizowania współczesnych procesów społecznych. Mają one ilustrować specyfikę i kondycję kultur, ekonomii, polityk, społeczności czy też po prostu codziennych działań. Kuligowski i Stanisz planowali skupić się zatem na zagadnieniach mobilności oraz przepływu, przede wszystkim $\mathrm{w}$ ich materialnym wymiarze, poprzez pryzmat przedmiotów. W zakresie panelu chcieli ulokować problematykę globalno- 
ści i transnacjonalności przedmiotów oraz ich cyrkulacji; zająć się kulturowym i społecznym wymiarem przepływu towarów; kulturowym i społecznym wymiarem transportu rzeczy (na przykład zjawiskiem konteneryzacji); materialnym wymiarem automobilności; estetyką kultur w ruchu; kulturą materialną towarzyszącą migracji, turystyce i innym formom przemieszczania się (na przykład rzeczy w podróży); przyjrzeć się rzeczom jako manifestacjom tożsamości i przynależności w warunkach globalnego przepływu.

Wobec podobnej problematyki zgłoszonych propozycji — choć nieco różniących się sposobem rozumienia kultury, ruchu i rzeczy — postanowiono połączyć je w jednym panelu pod nazwą, którą nosi także ten numer „Prac Kulturoznawczych” — „Mobilność rzeczy”. Większość tekstów, które w nim są zaprezentowane, ma swoje źródło w wystąpieniach wygłoszonych podczas Zjazdu. Kompromisowa formuła, która połączyła pomysłodawców panelu, odzwierciedla się także w większości artykułów, które łączą zainteresowanie rzeczami i ludźmi w ruchu.

Izolda Topp 